\title{
ON THE RATES OF GROWTH OF GRAINS AND GRYSTALS IN SOUTH POLAR FIRN
}

\author{
By Anthony J. Gow \\ (U.S. Army Terrestrial Sciences Center, Hanover, New Hampshire 03755, U.S.A.)
}

Abstract. The size of firn crystals as a function of age has been investigated in thin sections to a depth of $49 \mathrm{~m}$ at the South Pole. Grain cross-sections increased in size from $0.24 \mathrm{~mm}^{2}$ at $0.1 \mathrm{~m}$ depth to $0.63 \mathrm{~mm}^{2}$ at $10 \mathrm{~m}$. Crystals, as distinct from grains, increased in size from 0.18 to $0.43 \mathrm{~mm}^{2}$ over the same interval, implying that grains are generally composed of just one or two crystals rather than several as is frequently contended. The mean crystal cross-section increased linearly with the age of the firn at a rate of $0.0006 \mathrm{~mm}^{2}$ year $^{-1}$; in 388 year old firn at $49 \mathrm{~m}$ the crystal size measured $0.63 \mathrm{~mm}^{2}$. Analysis of crystal-growth data from other locations in Antarctica and Greenland also revealed a strong linear relationship between the mean cross-sectional areas $\left(D^{2}\right)$ of crystals $\left(\right.$ in $\mathrm{mm}^{2}$ ) and their ages in years $(t)$, i.e. $D^{2}=D_{\mathrm{o}}{ }^{2}+K t$. The fact that the temperature dependence of the crystal growth rate $K$ can be expressed very satisfactorily in an equation of the form $K=K_{\mathrm{o}} \exp (E / R T)$ confirms predictions that crystal growth in firn is essentially analogous to grain growth in metallic and ceramic sinters. An extrapolation of available data indicates that crystal growth rates in dry firn could be expected to vary by two orders of magnitude $\left(0.0003\right.$ to $0.03 \mathrm{~mm}^{2}$ year $\left.{ }^{-1}\right)$ over the temperature range $-60^{\circ}$ to $-15^{\circ} \mathrm{C}$. A method of utilizing crystal growth-mean annual temperature data to determine accumulation rates in snow is demonstrated.

RÉsumé. De l'accroissement des quantités de grains et cristaux dans le névé du Pôle Sud. La grosseur des cristaux de névé en fonction de l'âge a été étudié en lames minces à une profondeur de $49 \mathrm{~m}$ au Pôle Sud. Les coupes transversales augmentent de $0,24 \mathrm{~mm}^{2}$ a $0,63 \mathrm{~mm}^{2}$ lorsqu'on part d'une profondeur de $0, \mathrm{I} \mathrm{m}$ pour atteindre Io $\mathrm{m}$. Les cristaux se différenciant des grains croissent de $0,18 \mathrm{~mm}^{2}$ à $0,43 \mathrm{~mm}^{2}$ dans le même intervalle, les grains étant supposés généralement composés de un au deux cristaux à l'apposé de plusieurs comme c'est fréquemment dit. La coupe transversale de cristal moyen augmente de façon linéaire en fonction de l'âge du névé jusqu'à une quantité de $0,0006 \mathrm{~mm}^{2} \mathrm{an}^{-1}$. Dans un névé datant de 388 ans à $49 \mathrm{~m}$, l'épaisseur de cristal mesure $0,63 \mathrm{~mm}^{2}$. L'analyse des données de croissance de cristal d'autres emplacements en Antarctique et au Groenland révèle aussi un grand rapport linéaire entre les régions à coupes transversales moyennes

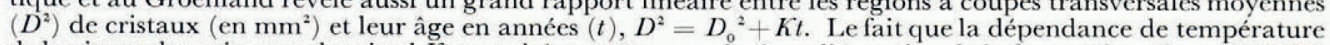
de la vitesse de croissance de cristal $K$ peut aisément être exprimé par l'équation de la forme $K=K_{\mathrm{o}} \exp (E / R T)$ confirme les prédictions mentionnant la croissance de cristal dans le névé essentiellement analogue à la croissance de grain dans les travertins métalliques et céramiques. Une extrapolation de données disponibles indique que les quantités en croissance de cristal dans le névé sec peut être évalué variant à deux ordres de grandeur $\left(0,0003\right.$ à $\left.0,3 \mathrm{~mm}^{2} \mathrm{an}^{-1}\right)$ au-dessus de la température s'échelonnant entre $-60^{\circ}$ et $-15^{\circ} \mathrm{C}$. Une méthode utilisant les données de température annuelles moyennes de cristal est décrite pour déterminer les quantités d'accumulation dans la neige.

Zusammenfassung. Die Wachstumsgeschwindigkeit von Körnern und Kristallen in Firn am Südpol. Die Grösse von Firnkristallen in Abhängigkeit von ihrem Alter wurde am Südpol mit Dünnschliffen bis zu einer Tiefe von $49 \mathrm{~m}$ untersucht. Die Korn-Querschnitte nahmen von $0,24 \mathrm{~mm}^{2}$ in o, $\mathrm{m}$ Tiefe bis o,6 $\mathrm{mm}^{2}$ in $10 \mathrm{~m}$ Tiefe zu. Die Grösse von Kristallen, soweit sie sich von Körnern unterschieden, wuchs im selben Bereich von $0,18 \mathrm{~mm}^{2}$ bis $0,43 \mathrm{~mm}^{2}$; dabei zeigte sich, dass Körner im allgemeinen eher nur aus einem oder zwei Kristallen zusammengesetzt sind als aus mehreren, wie häufig behauptet wird. Der mittlere Kristall-Querschnitt nahm linear mit dem Alter des Firns in einem Ausmass von $0,0006 \mathrm{~mm}^{2}$ pro Jahr zu; in $388 \mathrm{Jahre}$ altem Firn bei $49 \mathrm{~m}$ Tiefe betrug die Kristallgrösse $0,63 \mathrm{~mm}^{2}$. Die Analyse von Kristallwachstumsdaten von anderen Stellen in Antarktika und Grönland ergab ebenfalls eine streng lineare Beziehung zwischen den mittleren Querschnittsflächen $\left(D^{2}\right)$ der Kristalle (in $\mathrm{mm}^{2}$ ) und ihrem Alter $(t)$ in Jahren, nämlich: $D^{2}=D_{\mathrm{o}}^{2}+K t$. Die Tatsache, dass die Temperaturabhängigkeit der Kristallwachstumsgeschwindigkeit $K$ sehr befriedigend durch eine Gleichung von der Form $K=K_{\mathrm{o}} \exp (E / R T)$ ausgedrückt werden kann, bestätigt Voraussagen, dass das Kristallwachstum in Firn in wesentlich analog zum Kornwachstum in metallischen und keramischen Sintern verläuft. Eine Extrapolation verfügbarer Daten zeigt, dass Unterschiede der Kristallwachstumsgeschwindigkeit in trockenem Firn bis zu zwei Grössenordnungen (o,ooo3 bis $0,03 \mathrm{~mm}^{2}$ pro Jahr) im Temperaturbereich von $-60^{\circ}$ bis $-15^{\circ} \mathrm{C}$ erwartet werden können. Es wird eine Methode aufgezeigt, mit der Daten des Kristallwachstums und der mittleren Jahrestemperatur zur Bestimmung des Schneeauftrags benutzt werden können.

\section{INTRODUCTION}

The transformation of snow to ice in polar glaciers proceeds via two principal mechanisms, densification and recrystallization. Densification has to do with the elimination of pore space until the firn is no longer permeable, whereas recrystallization is involved with changes in the granular and crystalline structure of the snow as it densifies. The overall transformation has been described variously as diagenesis (Paulcke, 1934; Benson, 1959, 1962; Anderson and 
Benson, I963), metamorphism (Bader and others, I939) and sintering. So far, studies of this transformation have tended to concentrate on densification, and detailed investigations of the structure of polar firn have been limited to a few locations only. These include observations to roo $\mathrm{m}$ depth at Maudheim (Schytt, 1958) and to $45 \mathrm{~m}$ depth at Southice (Stephenson and Lister, 1959; Stephenson, 1967) in Antarctica, and the snow-structure studies conducted by Fuchs (1959) and Nakaya and Kuroiwa ( 1967 ) to depths of $46 \mathrm{~m}$ and $26 \mathrm{~m}$, respectively, at Site 2, Greenland.

In the present study, measurements have been made of the growth of crystals and grains in the top $49 \mathrm{~m}$ of the firn at Amundsen-Scott (South Pole) station. The objectives of this study were to (I) ascertain the time rate of growth of crystals and grains at the very low temperatures prevailing at the South Pole, and (2) evaluate the temperature dependence of this growth in conjunction with data obtained at other locations in Antarctica and Greenland.

\section{SAMPLING}

Samples were obtained from a $28 \mathrm{~m}$ deep snow mine and from cores from a hole drilled at the bottom of the mine to a depth of $49 \mathrm{~m}$ below the surface. All samples were selected randomly, without regard to grain-size or visible stratigraphic structure. Densities of samples ranged from $0.32 \mathrm{Mg} \mathrm{m}^{-3}$ near the surface to $0.65 \mathrm{Mg} \mathrm{m}^{-3}$ at $49 \mathrm{~m}$. The current rate of snow accumulation at the South Pole is $70 \mathrm{~kg} \mathrm{~m}^{-2}$ year $^{-1}$ and the age of the firn at $49 \mathrm{~m}$ depth is estimated at 388 years. The temperature below $10 \mathrm{~m}$ is virtually constant at $-5^{\mathrm{I}}{ }^{\circ} \mathrm{C}$. Detailed results of these and related glaciological studies at the South Pole are to be found in Giovinetto (1960), Gow and Ramseier ( 1963 ), Picciotto and others (1964), Epstein and others (1965) and Gow (1965).

\section{Preparation of Thin Segtions}

In firn, as in other well-bonded aggregates, e.g. sedimentary rocks, and metallurgical and ceramic sinters, the only feasible method of investigating the size and structural arrangement of particles is to prepare thin or polished sections. Most methods of preparing thin sections of snow require preliminary filling of the pore spaces to facilitate mounting and to reinforce the structure against breakage during sectioning. A number of liquid fillers have been used for this purpose, including tetrabromoethane (Bader and others, 1939), diethylphthalate (Schytt, I958; Stephenson and Lister, I959) and aniline (Kinosita and Wakahama, I959; Nakaya and Kuroiwa, I967). Aniline was used in the present study. Water-saturated aniline freezes at - I I ${ }^{\circ} \mathrm{C}$, does not noticeably deform the snow structure on freezing and melts out to a transparent isotropic liquid. Other advantages are its low solubility for water, low viscosity and good wettability. The principal disadvantage of aniline is that it is a toxic material that must be handled with care even at low temperatures. It should be pointed out here that this direct use of aniline is in no way associated with the staining properties of aniline dye, a derivative of aniline.

Thin sections were prepared in essentially the same manner as described by Kinosita and Wakahama (1959). Small blocks of firn measuring $3 \times 3 \times 1 \mathrm{~cm}$ were immersed in watersaturated aniline at $-7^{\circ} \mathrm{C}$ and when fully impregnated were allowed to congeal at $-20^{\circ} \mathrm{C}$. After freezing a $5 \times 7.5 \mathrm{~cm}$ microscope slide to one side of the block, the other side was planed smooth with a heavy sledge-type microtome and a second glass slide frozen onto the prepared surface. The block was cut in two on a band saw and the final sectioning was performed on the microtome. The remainder of the sample (with glass slide attached) was retained for making additional sections as needed. The thickness of the finished section measured approximately one-half the average grain diameter of the specimen. Sections could be prepared in as little as half-an-hour with this technique, which yields much better material for examining firn structure than either the replica method (Fuchs, I956, I959) or the "red paste" technique 
used by Shimizu (1958). A Bausch and Lomb extension camera fitted with polarizers was used to obtain structure photographs of each thin section. Best results are obtained if the temperature is raised to about $-7^{\circ} \mathrm{C}$ to allow all interstitial aniline to melt. Photographs were taken at $\times$ Io magnification with fine-grained panchromatic sheet film measuring $17.5 \times 12.5$ $\mathrm{cm}$. A single photograph of this size generally contains enough crystals for analyzing the average crystal size of a sample. Actual measurements were made on contact prints which also constitute a ready source of "structure pictures" that can be compared and evaluated at a moment's notice.

\section{Distinction Between Grains and Crystals}

Snow is a granular material in which the individual grains may be composed of more than one crystal. This distinction between grains and crystals is best observed in thin sections placed between crossed polaroids; different crystals in the same grain exhibit different birefringence colors because of variations in orientation. Whereas crystals were found to retain relatively simple outlines at all depths at the South Pole, grains did not, principally because of the growth of intergranular bonds which cause virtually complete obscuration of individual outlines at about ro $\mathrm{m}$ depth. Only crystals could be distinguished satisfactorily for size analysis below $\mathrm{r} 0 \mathrm{~m}$.

\section{Grain- and Crystal-size Measurements}

The determination of grain and crystal size in thin or polished sections usually involves measurements of either the diameter or the cross-sectional area of particles. Seligman (I949), for example, employed the method of the least-circle diameter using a set of root-mean-square diameters ranging from 0.25 to $10 \mathrm{~cm}$ to measure grain-size in rubbings of ice. Ahlmann and Droessler (1949) preferred to measure the longest and shortest axes of ice grains and to compute cross-sectional areas from these data. Schytt (1958) and Stephenson (1967) employed much the same method in their studies of crystal growth in Antarctic firn. In general, however, the average particle size obtained from thin-section analysis will be less than the true

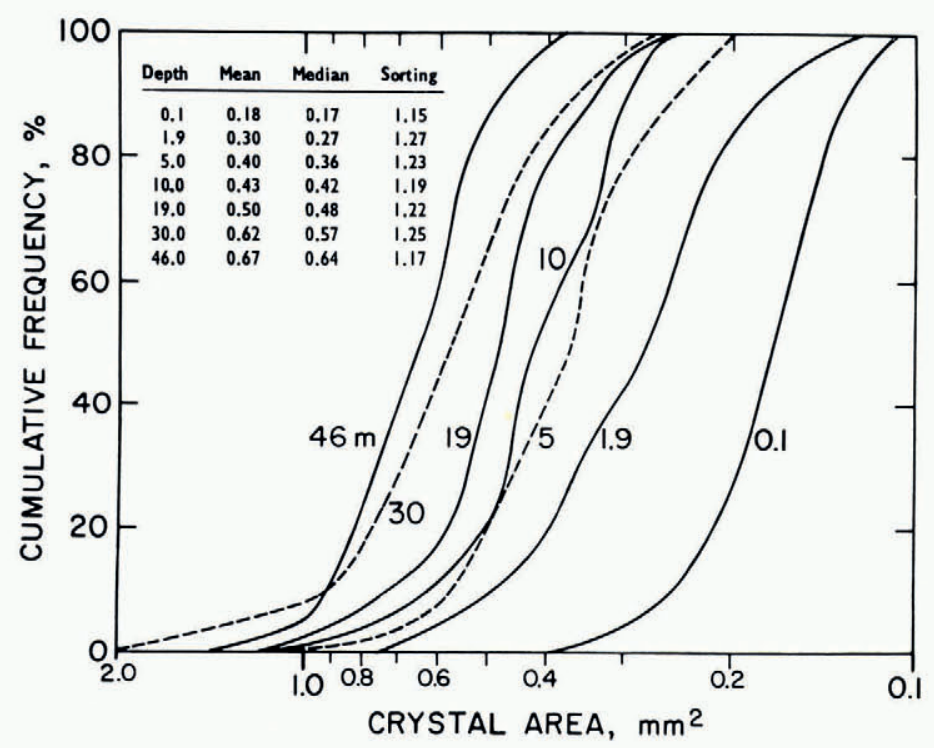

Fig. I. Representative cumulative frequency curves of crystal areas in South Pole firn. 
value simply because a section seldom cuts crystals at their maximum diameter. Krumbein (1935), for example, found with sections of uniform spherical grains that the most frequent diameter (or mode) was only about $80 \%$ of the true modal diameter, i.e. the modal crosssection will measure less than $64 \%$ of its true value. Variations in particle shape also complicate the problem which is further compounded by the lack of knowledge concerning the actual distribution of particle sizes within the original sample.

A cursory examination of the grains obtained by disaggregating several individual snow layers at the South Pole indicated a certain uniformity of size and shape of the constituent grains in each layer. From these observations it might be deduced that the smaller crosssections in a thin slice or section are due more to under-average cuts than to under-sized particles (grains or crystals). Since under-sized cross-sections exert a disproportionate influence on the average particle size it was decided to restrict measurements of crystal size at the South Pole to the 50 largest crystals in each section. With the exception of very fine-grained layers in the top $2 \mathrm{~m}$, these 50 largest crystals constitute at least $25 \%$ of the total number of crystals in a section measuring $\mathrm{I} .75 \times \mathrm{r} .25 \mathrm{~cm}$. The mean crystal size obtained in this way is believed

Table I. Crystal-size Measurements in Firn at the South Pole. (Ages Calculated on the Basis of a Constant Accumulation Rate of $70 \mathrm{~kg} \mathrm{~m}^{-2}$ year $^{-1}$ )

\begin{tabular}{|c|c|c|c|c|c|}
\hline $\begin{array}{l}\text { Depth } \\
\mathrm{m}\end{array}$ & $\begin{array}{l}\text { Age } \\
\text { years }\end{array}$ & $\begin{array}{c}\text { Mean crystal size } \\
\mathrm{mm}^{2}\end{array}$ & $\begin{array}{l}\text { Depth } \\
\mathrm{m}\end{array}$ & $\begin{array}{l}\text { Age } \\
\text { years }\end{array}$ & $\begin{array}{c}\text { Mean crystal size } \\
\mathrm{mm}^{2}\end{array}$ \\
\hline O.I & I & 0.18 & 25 & I 76 & 0.55 \\
\hline 0.6 & 3 & 0.30 & 26 & I 84 & 0.44 \\
\hline 1.2 & 6 & $0.3^{2}$ & 28 & 201 & $0.5^{\circ}$ \\
\hline I.9 & 10 & 0.30 & 30 & 218 & 0.62 \\
\hline 2.9 & 16 & $0.5^{I}$ & $3^{2}$ & ${ }_{23} 6$ & 0.49 \\
\hline $3 \cdot 5$ & I9 & 0.55 & 34 & 254 & $0.6 \mathrm{I}$ \\
\hline 5 & 28 & $0.4^{\circ}$ & 35 & 262 & $0.5^{6}$ \\
\hline 6 & 35 & $0.4^{\mathrm{I}}$ & 37 & 280 & $0.5^{2}$ \\
\hline 7 & $4^{2}$ & $0.4^{\mathrm{I}}$ & $3^{8}$ & 289 & 0.64 \\
\hline 9 & 55 & 0.53 & 39 & 298 & $0.5^{\circ}$ \\
\hline IO & 62 & 0.43 & $4^{I}$ & $3^{16}$ & $0.6 \mathrm{I}$ \\
\hline I I & 69 & 0.44 & 42 & 325 & $0.5 \mathrm{I}$ \\
\hline I 5 & $9^{8}$ & 0.45 & 43 & 334 & 0.63 \\
\hline 16 & 105 & 0.54 & 44 & 343 & 0.59 \\
\hline 17 & I 14 & $0.4^{2}$ & 45 & $35^{2}$ & $0.5^{\circ}$ \\
\hline 19 & 1 29 & $0.5^{\circ}$ & $4^{6}$ & 361 & 0.67 \\
\hline 21 & I 45 & $0.5^{8}$ & 47 & 370 & 0.64 \\
\hline 22 & I $5^{2}$ & 0.55 & $4^{8}$ & 379 & 0.77 \\
\hline 23 & 160 & $0.4^{6}$ & 49 & 388 & 0.63 \\
\hline
\end{tabular}

to yield a more realistic value than that based on measurements of all the crystals in a section or a random selection of crystals. Crystal cross-sectional areas were computed from measurements of the length and breadth made with a "pocket comparator" (simply a magnifying glass enscribed with suitable scales) on large contact prints. Crystal-size distributions of a number of representative samples of South Pole firn are shown in Figure I. All curves are characterized by a relatively narrow range of crystal sizes or high degree of sorting. Crystal-size data for all samples are presented in Table I and Figure 2. Measurements of grain cross-sections to $10 \mathrm{~m}$ depth are given in Table II.

\section{Results and Discussion}

Grain cross-sections at the South Pole were observed to increase in size from approximately $0.24 \mathrm{~mm}^{2}$ at $0.1 \mathrm{~m}$ to $0.63 \mathrm{~mm}^{2}$ at io $\mathrm{m}$. Crystal cross-sections, as distinct from grains, also increased between two- and three-fold from 0.18 to $0.43 \mathrm{~mm}^{2}$ over the same depth interval. These data (see Table II for grain-crystal relations) would indicate that grains and crystals tend to maintain a fairly constant growth ratio (I.4: I) during the early stages of recrystallization and that most grains are composed of just one or two crystals and not several as is frequently 


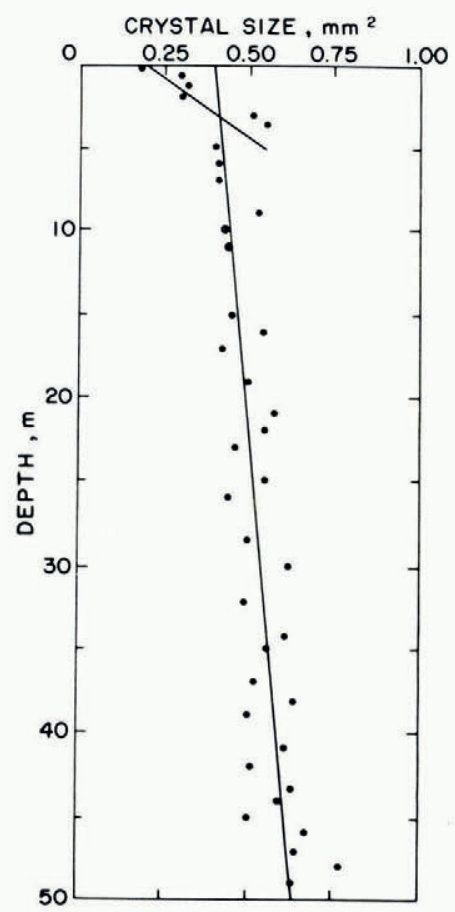

Fig. 2. Firn crystal size versus depth at the South Pole.

contended. Schytt (I958) also recorded a three-fold growth of crystals in the top ro m of firn at Maudheim. The fact that he failed to detect any significant increase in grain-size between the surface and $10 \mathrm{~m}$ depth clearly indicates that the crystals must have grown at the expense of grains. The ratio of grain cross-section to crystal cross-section at $10 \mathrm{~m}$ at Maudheim was I.36: I, very similar to that observed at the South Pole. Stephenson's (1967) data from

Table II. Grain-size and Grain-Crystal-size Relationships in Firn at the South Pole. Results Based on Measurements of Cross-sectional Areas of 5o Largest Crystals and Grains in a Section Measuring $1.75 \times 1.25 \mathrm{~cm}$

$\begin{array}{cc}\begin{array}{c}\text { Deplh } \\ \mathrm{m}\end{array} & \begin{array}{c}A \\ \text { Mean } \\ \text { grain-size } \\ \mathrm{mm}^{2}\end{array} \\ 0 . \mathrm{I} & 0.24 \\ 0.6 & 0.42 \\ 1.2 & 0.46 \\ 1.9 & 0.55 \\ 2.9^{*} & 0.5 \mathrm{1} \\ 3.5^{*} & 0.55 \\ 5.0 & 0.56 \\ 5.5 & 0.6 \mathrm{1} \\ 6.0 & 0.57 \\ 7.5 & 0.57 \\ 8.5 & 0.58 \\ 9.5 & 0.58 \\ 10.0 & 0.63 \\ 11.0 & 0.58\end{array}$

$\begin{array}{cc}\begin{array}{c}B \\ \text { Mean crystal size } \\ \mathrm{mm}^{2}\end{array} & A / B \\ 0.18 & \\ 0.30 & 1.33 \\ 0.3^{2} & 1.40 \\ 0.30 & 1.44 \\ 0.5 \mathrm{I} & 1.83 \\ 0.55 & 1.00 \\ 0.4 \mathrm{O} & 1.00 \\ - & \mathrm{1} .44 \\ 0.4 \mathrm{I} & - \\ - & \mathrm{1} .39 \\ - & - \\ - & - \\ 0.43 & - \\ 0.44 & 1.47 \\ & 1.32\end{array}$

* These two samples were composed substantially of monocrystalline grains. 
Southice also yield a grain* to crystal ratio of approximately $\mathrm{I} .4$ : I at $10 \mathrm{~m}$ depth. Grains, for all practical purposes, appear to reach a limiting size at about $10 \mathrm{~m}$ depth. Crystals of comparable cross-sectional area occur at $16-18 \mathrm{~m}$ depth at Maudheim and Southice but not until nearly $50 \mathrm{~m}$ at the South Pole. However, it seems worth noting that the density of the firn at these levels is much the same at all three locations, $0.62-0.64 \mathrm{Mg} \mathrm{m}^{-3}$.

The much greater rates of growth of grains and crystals in the top $4 \mathrm{~m}$ at the South Pole can probably be attributed to the effects of sustained temperature gradients in a snowpack that is accumulating very slowly. These dampen out rather rapidly below $4 \mathrm{~m}$. Virtually constant temperatures (these approximate closely the mean annual surface air temperature) prevail below ro $\mathrm{m}$, so that the growth of firn crystals at the South Pole can be considered analogous to the process of "crystal" growth in isothermally sintered aggregates in metals and ceramic materials (Burke and Turnbull, I952; Burke, I958).

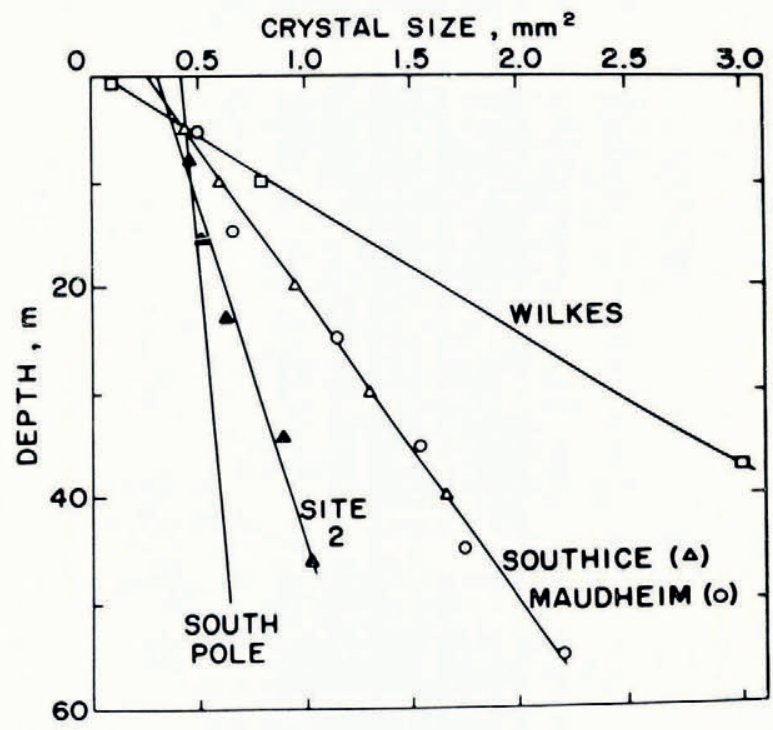

Fig. 3. Crystal-size variations with depth of firn in Greenland and Antarctica. Data sources: Site 2, Greenland (Fuchs, 1959); Southice (Stephenson and Lister, 1959); Maudheim (Schytt, 1953); Wilkes (Hollin and others, 1961).

Crystals only could be distinguished below io $\mathrm{m}$, and over the interval io to $49 \mathrm{~m}$ the size of crystals increased approximately linearly at the rate of $0.005 \mathrm{~mm}^{2}$ per $\mathrm{m}$. At $49 \mathrm{~m}$ the average crystal cross-section measured $0.63 \mathrm{~mm}^{2}$. The mean value of the deviations from the straight line in Figure 2 is less than $0.06 \mathrm{~mm}^{2}$ and the maximum deviation (at $48 \mathrm{~m}$ ) is $0.14 \mathrm{~mm}^{2}$. Extrapolation of this straight line to the estimated depth ( $\left.10 \mathrm{~m}\right)$ of the firn-ice transition would give a mean crystal size of nearly $1.00 \mathrm{~mm}^{2}$ at $\mathrm{I}$ io $\mathrm{m}$. A comparison of the South Pole data with other crystal-size measurements from Antarctica and Greenland (Fig. 3) demonstrates clearly the retarding effect on crystal growth of the very low temperatures prevailing at the South Pole. This occurs in spite of the fact that the firn is considerably older and has, as a consequence, been recrystallizing for a longer period of time at the South Pole than at corresponding depths at the other locations.

* Schytt and Stephenson both measured grain diameters and not cross-sectional areas. These latter values were computed from their original data on the assumption that the grains are spherical. 
It is interesting to note that all growth curves except the one for Site 2, Greenland, in Figure 3 intersect at $5 \mathrm{~m}$ depth where the mean crystal size is about $0.45 \mathrm{~mm}^{2}$. Virtually identical profiles at Maudheim and Southice probably reflect a balance between temperature (much higher temperatures at Maudheim) on the one hand and the time factor (much older snow at Southice) on the other.

A plot of crystal size versus depth is useful for characterizing firn-structure changes in a glacier. However, with regards growth rates and growth mechanisms, a much more meaningful set of data is likely to be provided by a plot of crystal size versus time. The elapsed time (or age of a sample) will depend on the rate of accumulation. If the effect of load per se is ignored and it is assumed for simplicity that the rate of accumulation remains constant at a particular location, then the snow load $(\sigma)$ at any depth will be directly proportional to the

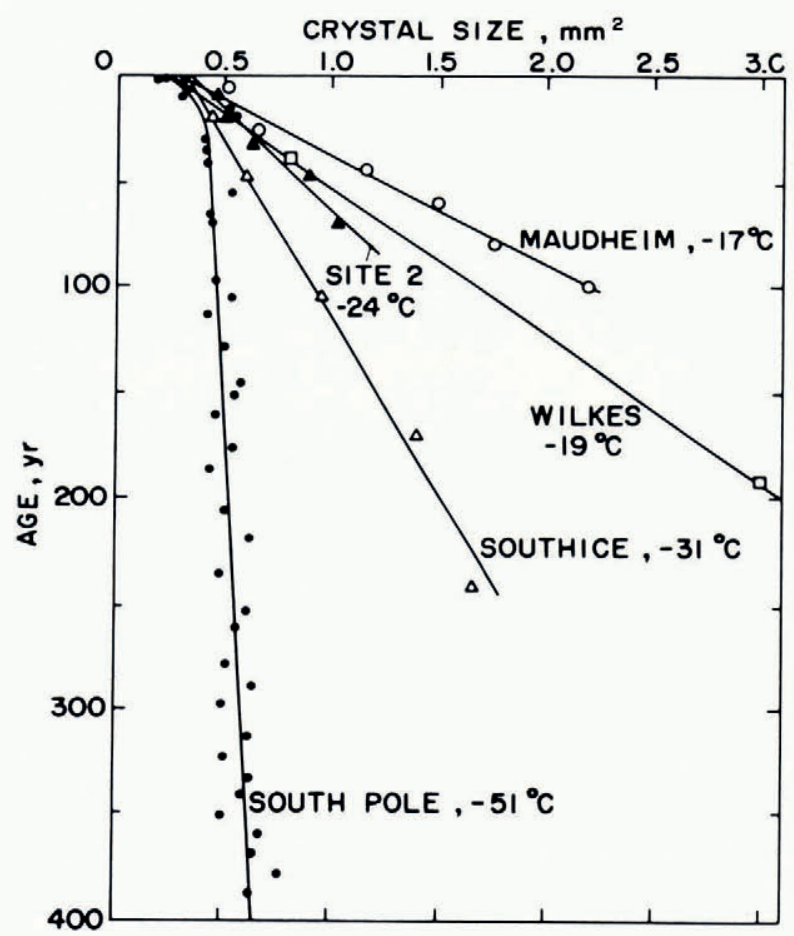

Fig. 4. Time rate of growth of crystals in polar firn. Ages calculated on the basis of constant accumulation rates of: $70 \mathrm{~kg} \mathrm{m-2}$ year-1 at South Pole; $100 \mathrm{~kg} \mathrm{~m}^{-2}$ year ${ }^{-1}$ at Southice; $400 \mathrm{~kg} \mathrm{~m}^{-2}$ year ${ }^{-1}$ at Site 2, Greenland; $\mathrm{I}_{30} \mathrm{~kg} \mathrm{~m}^{-2}$ year-1 at Wilkes ; $370 \mathrm{~kg} \mathrm{~m}^{-2}$ year $^{-1}$ at Maudheim. Io $\mathrm{m}$ temperatures at each location are indicated in the figure.

elapsed time $(t)$, i.e. $\sigma=A t$, where $A$ is the mean accumulation rate. In order to determine the age of a sample at any particular depth the snow load $\sigma$ (obtained by integrating the depthdensity curve to the appropriate depth) is simply divided by the rate of accumulation $A$.

Assuming a constant value of accumulation of $70 \mathrm{~kg} \mathrm{~m}^{-2}$ year-1 at the South Pole, it was found (Fig. 4) on recalculating data from Figure 2 that the mean crystal cross-section below $4 \mathrm{~m}$ increased essentially linearly with the age of the firn. This growth relationship can be expressed in the form

$$
D^{2}=D_{0}^{2}+K t
$$

where $D^{2}$ is the measured mean cross-sectional area $\left(\mathrm{mm}^{2}\right)$ of crystals in a firn sample of age $t$ (years) and $D_{0}{ }^{2}$ is the extrapolated mean cross-section at time zero. This, as already anticipated 

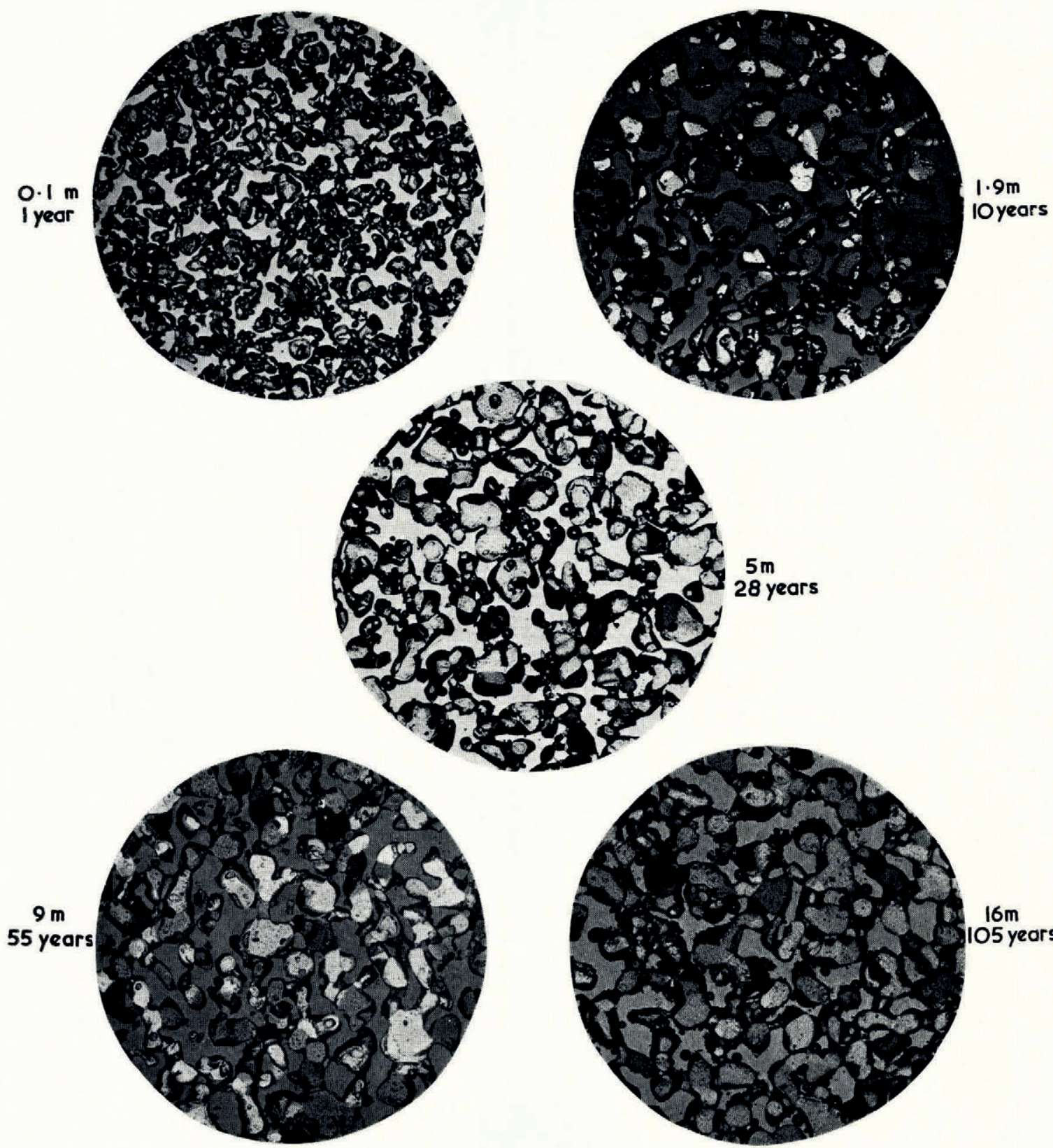

$40^{2}, 25$
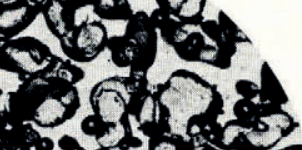

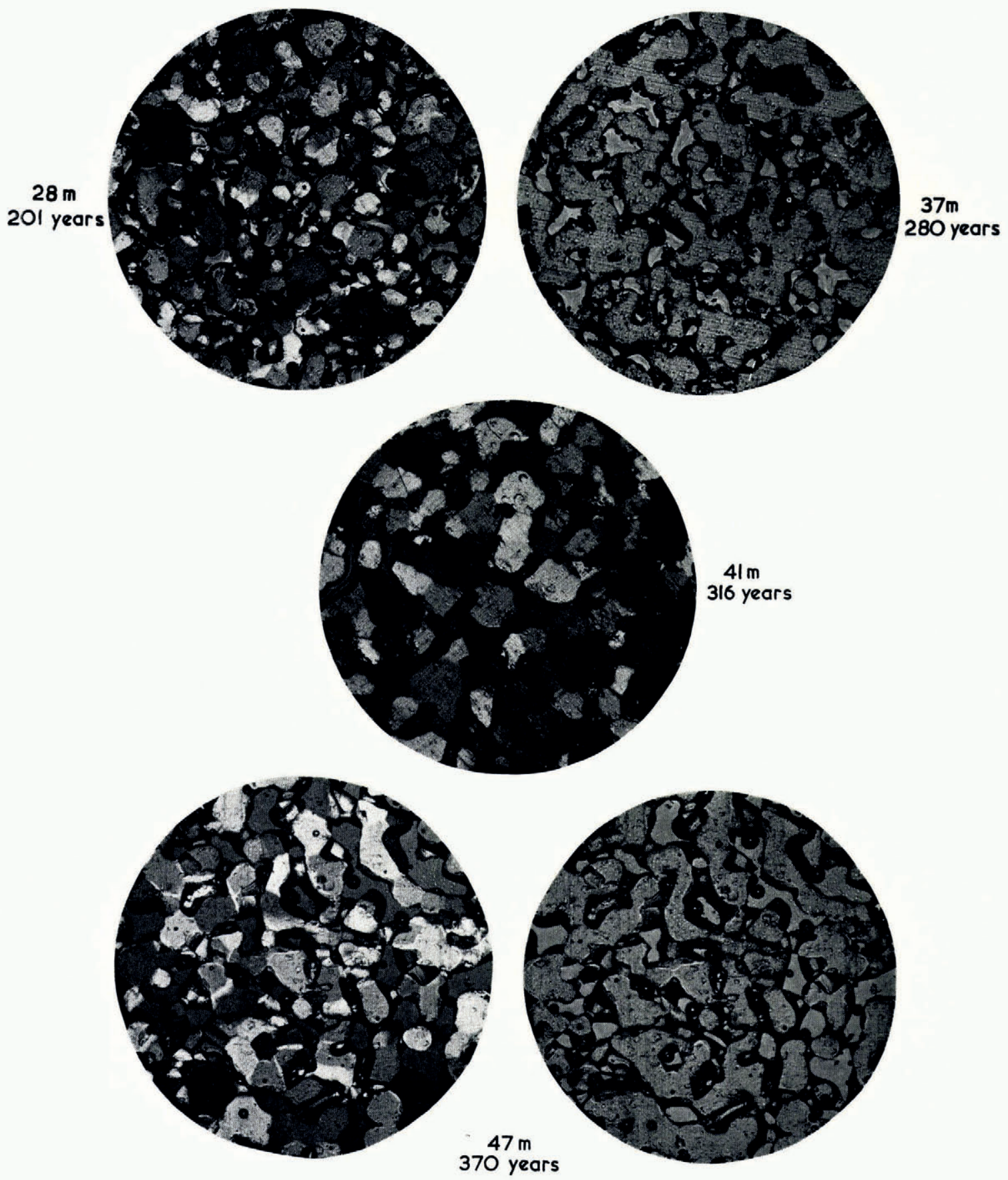

Fig. 5. 
from analogy with the sintering process, is precisely the relationship established for isothermal grain growth in metallurgy and ceramics. As is the case in sintering, the driving force of crystal growth in firn can almost certainly be attributed to the surface tension of the crystal boundaries. A sequence of structure pictures demonstrating the changes in the size, shape and bonding of crystals and grains as a function of the depth and age of the firn at the South Pole is presented in Figure 5 .

A recalculation of crystal-growth data from other locations in Antarctica and Greenland also reveals a strong linear relationship between the cross-sectional areas of crystals and their ages. It is clear also from Figure 4 that crystal-growth rates are strongly temperature dependent; the higher the firn temperature, the faster the growth. As indicated in Table III, this growth increases more than 30 -fold from $0.0006 \mathrm{~mm}^{2}$ year ${ }^{-1}$ at the South Pole to nearly

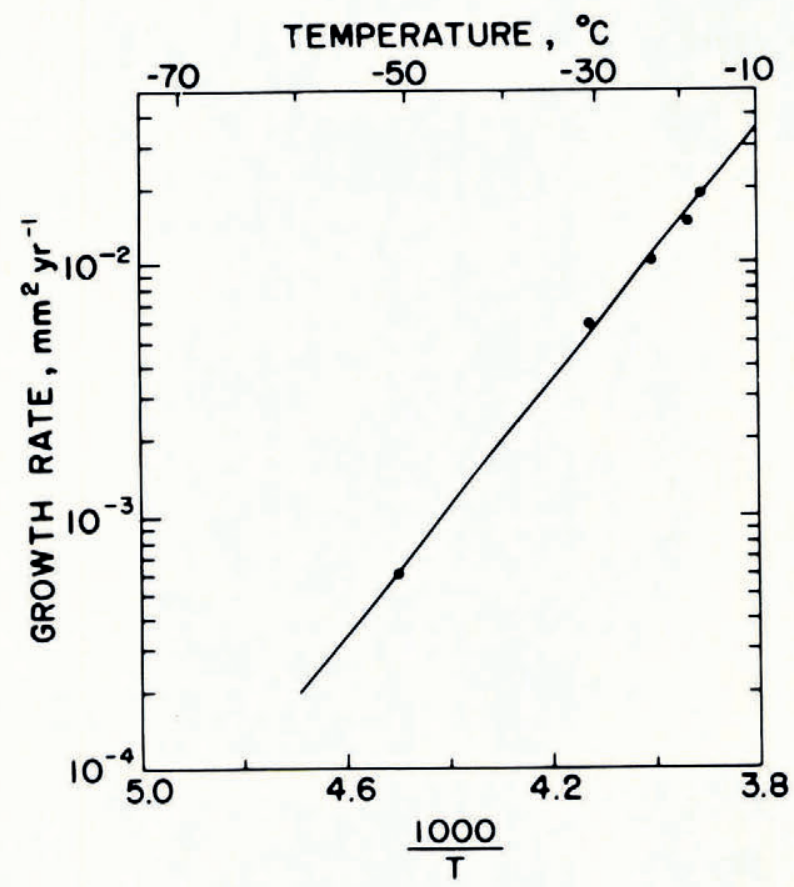

Fig. 6. Temperature dependence of crystal growth rates in polar firn.

$0.019 \mathrm{~mm}^{2}$ year $^{-1}$ at Maudheim. Furthermore, it appears that the temperature dependence of the growth of crystals in polar firn can be expressed in an equation of the form

$$
K=K_{\mathrm{o}} \exp (E / R T)
$$

where $K$ is the observed rate of growth of crystals $\left(K=\left(D^{2}-D_{0}{ }^{2}\right) / t\right), T$ is the snow temperature in degrees Kelvin, $K_{\mathrm{o}}$ is a constant, and $E$ and $R$ are the activation energy and gas constant, respectively. A plot of the growth-rate data versus $\mathrm{I} / T$ is given in Figure 6 , and the apparent activation energy obtained from the slope of the straight line is $4^{8} 570 \mathrm{~J} \mathrm{~mole}^{-1}$.

The temperature range of crystal-growth observations made so far in Antarctica, $-5 \mathrm{I}^{\circ}$ to $-17^{\circ} \mathrm{C}$, comes close to spanning the entire temperature range of the dry snow facies $\left(-60^{\circ}\right.$ to $\left.-15^{\circ} \mathrm{C}\right)$. An extrapolation of data in Figure 6 indicates that crystal-growth rates in Antarctica could be expected to vary by at least two orders of magnitude - from a rate of $0.0003 \mathrm{~mm}^{2}$ year $^{-1}$ at $-60^{\circ} \mathrm{C}$ to $0.03 \mathrm{~mm}^{2}$ year ${ }^{-1}$ at $-15^{\circ} \mathrm{C}$. 
Table III. Crystal-growth Rates $(K)$ of Polar Firn; Determined According to the Relation $D^{2}=D^{2}{ }_{0}+K t$ (See Text for Explanation of Sумвог.s)

Location

South Pole

Southice

Site 2, Greenland

Wilkes

Maudheim

Firn temper
$\begin{array}{r}{ }^{\circ} \mathrm{C} \\ -5 \mathrm{I} \\ -31 \\ -24 \\ -19 \\ -17\end{array}$

$D_{\mathrm{o}}{ }^{2}$
$\mathrm{~mm}^{2}$
$0.4^{1}$
0.35
0.36
0.25
0.32

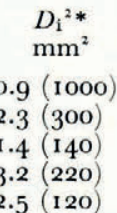

*xtrapolated values of mean crystal size at the firn-ice transition.

Numbers in parentheses are the estimated ages (in years) of crystals at the transition.

An important by-product of crystal-size measurements is that they provide data that could be used to obtain estimates of accumulation rates. The only change in presenting the data would be to replace the crystal size - age plot (which was obtained originally by assuming a constant accumulation rate) with a plot of crystal size versus snow load. From such a plot, it is possible to determine a load rate of growth which can be expressed in the units $\mathrm{mm}^{2}$ per $\mathrm{kg} \mathrm{m}^{-2}$. Knowing the firn temperature ( $\mathrm{r}$ o $\mathrm{m}$ temperature), Figure 6 can now be used to pick off the growth rate, $\mathrm{mm}^{2}$ year ${ }^{-1}$, appropriate to that temperature. To determine the mean accumulation rate, the time rate of growth of crystals obtained from Figure 6 is simply divided by the measured load rate of growth, i.e. $\frac{\mathrm{mm}^{2}}{\text { year }} / \frac{\mathrm{mm}^{2}}{\mathrm{~kg} \mathrm{~m}^{-2}}=\mathrm{kg} \mathrm{m}^{-2}$ year ${ }^{-1}$.

\section{Acknowledgements}

This study was sponsored by the Office of Antarctic Programs, U.S. Antarctic Research Program, and was funded by a grant from the National Science Foundation. The support of these institutions and the assistance in the field of various elements of Task Force 43, U.S. Navy, is gratefully acknowledged. I am grateful to Mr L. W. Stanley of U.S. Army CRREL for assisting with data analysis and to Dr W. F. Weeks for critically reviewing the manuscript.

MS. received 5 August 1968

\section{REFERENCES}

Ahlmann, H. W., and Droessler, E. G. 1949. Glacier ice crystal measurements at Kebnekajse, Sweden. Journal of Glaciology, Vol. I, No. 5, p. 268-74.

Anderson, D. L., and Benson, C. S. I963. The densification and diagenesis of snow. (In Kingery, W. D., ed. Ice and snow; properties, processes, and applications: proceedings of a conference held at the Massachusetts Institute of Technology, February I2-16, 1962. Cambridge, Mass., M.I.T. Press, p. 39I-4I I.)

Bader, H., and others. 1939. Der Schnee und seine Metamorphose, von H. Bader, R. Haefeli, E. Bucher, J. Neher, O. Eckel, C. Thams, P. Niggli. Beiträge zur Geologie der Schweiz. Geotechnische Serie. Hydrologie, Lief. 3. [English translation: U.S. Snow, Ice and Permafrost Research Establishment. Translation 14 , 1954.]

Benson, C. S. 1959. Physical investigations on the snow and firn of northwest Greenland, 1952, 1953 and 1954. U.S. Snow, Ice and Permafrost Research Establishment. Research Report 26.

Benson, C. S. 1962. Stratigraphic studies in the snow and firn of the Greenland ice sheet. U.S. Snow, Ice and Permafrost Research Establishment. Research Report 70.

Burke, J. E. 1958. Recrystallization and sintering in ceramics. (In Kingery, W. D., ed. Ceramic fabrication processes. Cambridge, Mass., M.I.T. Press, p. 120-31.)

Burke, J. E., and Turnbull, D. I952. Recrystallization and grain growth. Progress in Metal Physics, 3, p. $220-92$.

Epstein, S., and others. 1965. Six-year record of oxygen and hydrogen isotope variations in South Pole firn, by S. Epstein, R. P. Sharp and A. J. Gow. Journal of Geophysical Research, Vol. 70, No. 8, p. 1809-14.

Fuchs, A. 1956. Preparation of plastic replicas and thin sections of snow. U.S. Snow, Ice and Permafrost Research Establishment. Technical Report $4 \mathrm{I}$.

Fuchs, A. 1959. Some structural properties of Greenland snow. U.S. Snow, Ice and Permafrost Research Establishment. Research Report 42. Giovinetto, M. B. I960. Glaciology report for 1958, South Pole station. Ohio State University Research Foundation.
Report 825-2-Part IV. 
Gow, A. J. 1965. On the accumulation and stratification of snow at the South Pole. Fournal of Glaciology, Vol. 5 , No. 40 , p. $467-77$.

Gow, A. J., and Ramseier, R. O. 1963. Age hardening of snow at the South Pole. Fournal of Glaciology, Vol. 4, No. 35 , p. $521-36$.

Hollin, J. T., and others. I96r. Wilkes station glaciology, 1958, by J. T. Hollin, C. Cronk and R. Robertson. Ohio State University Research Foundation. Report 825-2-Part X.

Kinosita, S., and Wakahama, G. 1959. Thin sections of deposited snow made by use of aniline. Teion-kagaku: Low Temperature Science, Ser. A, [No.] 18, p. 35-45.

Krumbein, W. C. 1935. Thin-section mechanical analysis of indurated sediments. Fournal of Geology, Vol. 43 , No. 5 , p. $482-96$.

Nakaya, U., and Kuroiwa, D. 1967. Physical properties and internal structure of Greenland snow. (In Oura, $\mathrm{H}$., ed. Physics of snow and ice: international conference on low temperature science. ... 1966. . . Proceedings, Vol. I, Pt. 2. [Sapporo], Institute of Low Temperature Science, Hokkaido University, p. 953-71.)

Paulcke, W. 1934. Eisbildungen I. Der Schnee und seine Diagenese. Zeitschrift für Gletscherkunde, Bd. 2 I, Ht. 4-5, p. $259-82$.

Picciotto, E. E., and others. 1964. Rate of accumulation of snow at the South Pole as determined by radioactive measurements, by E. [E.] Picciotto, G. Crozaz and W. de Breuck. Nature, Vol. 203, No. 4943, p. 393-94.

Schytt, V. 1958. Glaciology. II. Snow studies at Maudheim.- Snow studies inland.-The inner structure of the ice shelf at Maudheim as shown by core drilling. Norwegian-British-Swedish Antarctic Expedition, 1949-52. Scientific Results, Vol. 4, A-C.

Seligman, G. 1949. The growth of the glacier crystal. Journal of Glaciology, Vol. I, No. 5, p. $254-67$.

Shimizu, H. 1958. Thin sections of deposited snow by red paste method. Teion-kagaku: Low Temperature Science, Ser. A, [No.] 17, p. $8 \mathrm{i}-86$.

Stephenson, P. J. I967. Some considerations of snow metamorphism in the Antarctic ice sheet in the light of ice crystal studies. (In Öura, H., ed. Physics of snow and ice : international conference on low temperature science. $\ldots 1966$. ... Proceedings, Vol. I, Pt. 2. [Sapporo], Institute of Low Temperature Science, Hokkaido University,

p. $725-40$.
Stephenson, P. J., and Lister, H. 1959. Preliminary results of the glaciological work on the Trans-Antarctic Expedition, 1955-58. Fournal of Glaciology, Vol. 3, No. 25, p. 426-31. 